\title{
Forty-Four Years of Polish Archaeoastronomical Research in Latin America
}

Stanisław Iwaniszewski

(iD) https://orcid.org/0000-0001-5365-7143

Instituto Nacional de Antropología e Historia

Posgrado en Arqueología, Escuela Nacional de Antropología e Historia e-mail: siwanisz@yahoo.com

\section{Abstract}

Since the late 1980s, there has been a considerable growth in the number of Polish contributions to the Latin American archaeoastronomy. Much of this interest in archaeoastronomy is an outcome of the scientific activities of Professor Andrzej Wiercinski who in the 1970s was fascinated with the claims for sophisticated Megalithic astronomy advocated by early British archaeoastronomers. The paper provides a brief description of the greatest Polish achievements in the field of Latin American archaeoastronomy.

Keywords: history of archaeoastronomy, Latin American archaeoastronomy 


\section{Introduction}

Decades of research work done by generations of Americanists have shown that indigenous populations in prehispanic America developed complex astronomies and calendars. However, since most of the Native American societies have left us no written record, the evidence for their astronomical skills has been mainly derived from the study of the alignments of archaeological remains to the rising and setting points of the heavenly bodies. A large number of monuments studied proved convincing arguments for the deliberate incorporation of celestial alignments into monumental architecture, identifying archaeological sites as locations where prehispanic elites erected enormous monuments that embodied astronomical knowledge. Since the 1970s, this kind of research has gradually been separated from the mainstream anthropology and archaeology and has developed under the general rubric of archaeoastronomy.

In 1974-1975 Professor Andrzej Wiercinski published a short paper on his discovery of a standardized megalithic yard in the measurements of the Sun Pyramid at Teotihuacan, thus revealing intricate astronomical knowledge encoded in the pyramid's dimensions. According to my knowledge, his paper is the first Polish contribution to the Latin American archaeoastronomy. This publication preceded the foundation of the Polish Society for Latin American Studies (PTSL) for nearly four years meaning that Polish archaeoastronomical research in Latin America is a little bit older than the existence of the Society. Therefore, celebrating the $40^{\text {th }}$ anniversary of PTSL may also be an excellent opportunity to revise and reassess the achievements of Polish contributions to Latin American archaeoastronomy. My aim is then to provide a short historical overview of the most outstanding results in this field. A second purpose is to provide, through the bibliography, more details about the research activity of Polish archaeoastronomers in Latin America.

\section{A few words on archaeoastronomy}

The term "archaeoastronomy" reached a broader academic audience post-1970s and originally denoted prehistoric astronomy, how ancient peoples perceived, understood and made use of their knowledge of celestial phenomena. Associated with the discovery of the astronomical nature of Stonehenge, archaeoastronomy arose through the particular interests of astrophysicists and historians of astronomy who compared non-Western forms of engagement with the celestial phenomena to modern astrophysics considering prehistoric observation spots as prototypes of modern observatories and the specialists commissioned to make the necessary observations, as the archetypes of modern scientists. Within such an approach, all material remains associated with specialized astronomical knowledge (rock-art 
sites, megaliths, pyramids, temples, churches, calendrical devices) became regarded as proofs of the scientific advancement of their builders or makers. Mathematical and geometrical properties found in monumental architecture, as well as alignments indicating celestial horizontal events, were perceived as features indicative of astronomical knowledge of their designers and builders. While some of these claims have been viewed with scepticism, particularly by archaeologists, many other scholars argued that relatively precise and complex astronomical and calendrical systems of knowledge as found in archaeological evidence required considerable development of cognitive skills of prehistoric skywatchers. This image eventually led to the idea that the ancient Mayan and Aztec cultures represented theocracies ruled by wise priests and astronomers (Berthelot 1949: 354-68; Thompson 1954).

Since celestial phenomena have the potential to denote time intervals involving astronomical observations through architectural alignments, the measurement of time often stands in pair with the development of indigenous measuring systems. The use of units of length was recognized by Alexander Thom $(1962,1964)$ who was one of the first to propose that the megalithic structures (stone rings and rows) in the British Isles were set out in terms of a standard measuring unit, the so-called megalithic yard of $0.829 \mathrm{~m}$.

\section{Andrzej Wierciński (1930-2003)}

In keeping with the processualist paradigm, Andrzej Wierciński (1983) advocated his functional theory of culture and cultural evolution. The emergence of megalithic monuments in Western Europe was an important index of the astrobiological worldview, which, according to Wiercinski, constituted the common core for ideologies and religions of the great civilizations of the Antiquity. The builders and users of megaliths were imagined as individuals possessing more profound knowledge based on an understanding of celestial movements which in later stages constituted theocratic elites. The accumulation of a complex astronomical knowledge paired with the increase of celestial symbolism that permeated both ideology and religion paved the way to the rise of theocracies with their full-time high-ranking astronomer-priests living in ceremonial centres, supported by the agricultural population settled in the country.

Professor Wierciński found such an astrobiological worldview in the architecture of Teotihuacan, the largest and highly planned city in the Mexican Highland. Even today, its rectangular street-grid seems to evoke the sense of an ordered harmony which finds its roots in the rotating heavens. The idea that the urban arrangement served to correlate celestial and terrestrial realms in order to present them as mutually corresponding parts of the cosmos has led Wierciński to study the possible ideological-cosmological factors that could have determined its unique layout. He 
assumed that the city's major monuments, the Pyramid of the Sun, the Pyramid of the Moon and the Pyramid of the Feathered Serpent (Quetzalcoatl), could have embodied the concept of the cosmic mountain.

From the perceived similarities of the skeletal remains at Olmec sites in Mexico to those of the Western African megalithic cultures, Wierciński hypothetically proposed that the ideological base influenced ancient Mesoamerican cultures stemmed from the megalithic cultures of Western Europe and Africa already associated by him with the idea of astrobiology. Since the megalithic builders in Western Europe and Africa used a measurement unit equivalent to $82.9 \mathrm{~cm}$, building on Thom's research, Wierciński $(1974-5 ; 1976,1977,1980)$ subsequently argued that the Teotihuacanos, the successors of the Olmecs, employed the same unit of measurement. Then, converting the features of the Pyramid of the Sun into the multiples of the megalithic yard, Wiercinski was able to demonstrate that their dimensions encoded various calendrical cycles as well as the synodic periods of visible planets. This information allowed Wierciński to conclude that like in the Middle East, also Teotihuacan pyramids were architectonic expressions of the archetype of the cosmic mountain, symbolically linking the Earth and the skies.

One of the important effects of Wierciński's research was the growing awareness of astronomical alignments encoded in prehistoric monuments and, consequently, the development of archaeoastronomy in Poland.

\section{Elżbieta Siarkiewicz (1941-2018)}

Elżbieta Siarkiewicz showed the importance of the Aztec (Mexica) tonalpohualli cycle for the computation of time and astronomy. The tonalpohualli has been defined as a mantic-divinatory counting system that operated complementarily with the vague year of 365 days.

Most calendar systems are based on the periodicity of the astronomical events, mainly on the motions of Sun (year), Moon (month), and the rotation of Earth (day). However, the 260-day cycle, the combination of the integers of 13 and 20, has no direct links to astronomical cycles. Nevertheless, this 260 -day cycle operated within the 365-day annual cycle, and therefore also had some calendrical function.

The variety of functions attributed to the tonalpohualli caused some conceptual chaos. The range of explications varies between the concepts of the tonalpohualli as a pure mantic-divinatory system independent of calendars and not designed to reckon the time and the idea of a cycle of days running without interruptions linked to some unspecified or unidentified natural or astronomical cycles. Without denying the existence of the mantic-divinatory function of the cycle of 260 days, Siarkiewicz (1995) proposed it was a kind of a tool that provided numerical codes 
both to create temporal units (of $13,20,40,52,65,78,80,91, \ldots 260, \ldots 360,364,365$, 584 days) and to annotate different units of time (i.e. those initiating with particular days in a cycles of 13 days, 20 days and 365 days). She has also shown the usefulness of the greater cycles of $260,364,365$ and 584 days to describe the movements of the celestial bodies and to predict recurrent phenomena in the sky. Furthermore, she has attempted to explain how the calculations of the solar (=tropical) year could be executed, developing a calendric-astronomical model that combined the Dresden Codex Venus and Eclipse tables with the computations of the tropical year.

\section{Robert Marcin Sadowski (1947-2010)}

As an astronomer, historian of astronomy and astrology, and a former student of Professor Włodzimierz Zonn, Robert M. Sadowski combined the knowledge of astrophysics with that of cultural anthropology. Invited by Professor Wiercinski to talk on ancient astronomy, he quickly became the regular attendant of professor's seminar, generously sharing his knowledge of astronomy necessary to verify anthropological interpretations.

In the decade of 1980, Sadowski was involved in Mariusz S. Ziolkowski project aiming to reconstruct the prehispanic Inca calendars. Sadowski's computations of celestial events allowed Ziolkowski to synchronize historical event with the astronomical ones in order to reconstruct the imperial calendar, used for the administration of Tawantinsuyu (consult Ziolkowski and Sadowski 1979, 1980, 1989). Sadowski was the original researcher, especially his later studies focused on the problems of the Hellenistic astrology and Arabian astronomy. His expert knowledge of the history of astrology was essential to infer the motives that could have guided Hernán Cortés to abandon Tenochtitlan in 1520 (Tomicki and Sadowski 1992). In those, “pre-computer days" Robert Sadowski' ability to date astronomical events retrieved from the historical, ethnohistorical and archaeological record was invaluable and certainly allowed Polish Latin Americanists to include archaeoastronomy to the standard research practices.

\section{Arnold Lebeuf (b. 1946)}

Arnold Lebeuf's interest in the study of astronomical and cosmological elements in ancient cultures was shaped by the topics discussed at the meetings "Astronomie et sciences humaines" organized from 1986 by Carlos Jaschek and Pierre Erny in the Astronomical Observatory and the University of Strasbourg. While in Poland, Lebeuf became a member of Professor Wiercinski's seminar. In the early 1990s, his research interest shifted towards the field of Latin American archaeoastronomy. 
After the collaborative work with Mariusz S. Ziolkowski (Ziolkowski and Lebeuf 1992a, 1992b, 1993) and Stanislaw Iwaniszewski (Lebeuf and Iwaniszewski 1994) he developed a series of independent research projects. The study of the vertical shaft at Xochicalco led Lebeuf (1995) to associate lunar phenomena with spatial and calendrical interrelationships and to propose a complex lunar religious and observational framework for this seventh-century city-state (Lebeuf 1995). Based on his knowledge of the solar and lunar eclipses derived from his earlier research in Europe, Arnold Lebeuf looked upon the eclipse table of the Dresden Codex. Since the document reflects, the indigenous Mesoamerican eclipse theory associated with its peculiar calendrical framework, Lebeuf proposed that the development of the ancient cosmological system was moulded by the ability of Mesoamerican day keepers to predict or anticipate the dates of which solar and lunar eclipses might occur.

\section{Mariusz S. Ziółkowski (b. 1953)}

From the beginning of his carrier, Mariusz Ziolkowski centred his research interests on the reconstruction of the Inca metropolitan calendar. In the last decade, he focused on the identification of ancient Inca observatory stations purposely designed to yield very precise astronomical observations. Because of the lack of sufficient space, and because Professor Ziolkowski continuously makes significant contributions to the field, I feel it necessary not to enter in more details here. $\mathrm{He}$ certainly did not say the last word in the Andean archaeoastronomy.

\section{Stanisław Iwaniszewski (b. 1953)}

Stanislaw Iwaniszewski was instrumental in the development of cultural astronomy. He has also carried out archaeoastronomical investigations on various archaeological sites in Mexico and inferred the Maya lunar theory from the Lunar Series displayed on monuments.

\section{Conclusions}

Polish Latin American archaeoastronomy was born in the 1980s, just a few years before the political transformation of the country, to a large extent thanks to research activities of Professor Wiercinski who gathered and motivated a group of younger scholars. The intellectual fervour produced by seminar meetings resulted 
in the creation of a small group of researchers searching for innovative and interdisciplinary solutions in the study of ancient societies. Their treated archaeoastronomy as:

a) a means to support data legitimizing phases in the cultural evolution of ancient societies (Wierciński);

b) a medium providing an absolute chronology to historical events or to verify historical statements (Ziolkowski and Sadowski, Tomicki and Sadowski). This approach defines archaeoastronomy as archaeometry;

c) a tool to infer the cognitive abilities associated with the celestial lore (Siarkiewicz, Lebeuf), archaeoastronomy as part of cognitive anthropology and archaeology;

d) part of landscape or skyscape archaeologies (Iwaniszewski);

e) part of a much wider thematic research field coined cultural astronomy (Iwaniszewski).

Unfortunately, the "generation gap" observed in many diverse fields of scientific investigation in Poland has also touched Latin American studies and raises concerns about the future development of this discipline in Poland. Current archaeoastronomy is no longer limited to the study of astronomical alignments, and its scope has moved out of the range of problems investigated in the 1980 os and 1990 . So in order to be familiar with the current theory, it is necessary to create research centres in Poland. Otherwise, the presence of Polish scholars in Latin American archaeoastronomy will be marginalized.

\section{Works Cited}

Berthelot, René. La pensé de l'Asie et l'astrobiologie. Paris: Payot, 1949 (1 ${ }^{\text {st }} \mathrm{ed}$. in 1938). Brykczyński, Piotr. “Astrologia w Palmyrze.” Studia Palmyreńskie 6-7 (1975): 47-109. Thom, Alexander. "The Larger Units of Megalithic Man." Journal of the Royal Statistical Society, A 127 (1964): 527-533.

Thom, Alexander. “The Megalithic Unit of Length.” Journal of the Royal Statistical Society, A 125 (1962): 275-295.

Thompson, J. Eric S. The Rise and Fall of Maya Civilization. Norman: University of Oklahoma Press, 1954.

\section{Archaeoastronomical works of Andrzej Wierciński}

“Megalithic Yard in Teotihuacan?” Almogaren 5-6 (1974-5): 271-276.

"Dark and Light Side of the Aztec Stone calendar and Their Symbolical Significance". Actas del XLI Congreso Internacional de Americanistas. México, D.F.: 1976, vol. II: 275-278.

"Pyramids and Ziggurats as the Architectonic representations of the Archetype of the Cosmic Mountain, Part 1." Almogaren 7 (1976): 199-210. 
Occasional Publications in Classical Studies. Museum of Anthropology, University of Northern Colorado, 1 (1976): 69-113.

"Time and space in the Sun Pyramid from Teotihuacan." Polish Contributions in New World Archaeology [Prace Komisji Archeologicznej nr 16], Kraków: Polska Akademia Nauk - Oddział w Krakowie, Part I (1977): 87-103.

Polish Contributions in New World Archaeology [Prace Komisji Archeologicznej nr 16], Kraków: Polska Akademia Nauk - Oddział w Krakowie, Part I (1977): $105-109$.

"Canon of the human body. Mexican measures of length and the Pyramid of Quetzalcoatl from Teotihuacan". Polish Contributions in New World Archaeology [Prace Komisji Archeologicznej nr 19], Kraków: Polska Akademia Nauk - Oddział w Krakowie, Part II (1980): 103-123.

\section{Archaeoastronomical works of Elżbieta Siarkiewicz}

"Un canon de eclipses lunares en el Códice Borgia. Prueba de interpretación". Ethnologia Polona 12 (1986): 79-84.

"Un canon de eclipses lunares en el Códice Borgia.", Etnoastronomías americanas. Eds. J. Arias de Greiff y E. Reichel D., Bogotá: Centro Editorial, Universidad Nacional de Colombia, 1987.

"The Cryptonumber Correction System of Venus Cycles in the Dresden Codex." Readings in Archaeoastronomy. Ed. S. Iwaniszewski, Warsaw: State Archaeological Museum at Warsaw and Department of Historical Anthropology, Institute of Archaeology, University of Warsaw, (1992): 87-97.

"The Moon, the thirteens and twenties, and the genesis of the 260 count system. An interpretation of pages 37-38 of the Dresden Codex: the Moon and Venus." European Meeting on Archaeoastronomy and Ethnoastronomy. Ed. C. Jaschek, Strasbourg: Publication de l'Observatoire Astronomique de Strasbourg, (1992): $160-171$.

"Un opúsculo de Fr. Andrés de Olmos insert en los memorials de Fr. Toribio de Benavente Motolinía." Diálogo intercutural - migración de discursos. Ed. M. Adamczyk, Warszawa: Centro de Estudios Latinoamericanos, (1993): 63-72.

"Un intento franciscano de conservar el calendario indígena en la Nueva España en el siglo XVI." Time and Astronomy at the Meeting of Two Worlds. Eds. S. Iwaniszewski, A. Lebeuf, A. Wierciński, and M. S. Ziółkowski, Studies and Materials 10. Warsaw: Center for Latin American Studies, University of Warsaw, (1994): 252-264.

El tiempo en el tonalamatl. Warszawa: Cátedra de Estudios Ibéricos, Universidad de Varsovia, 1995.

"Some Remarks on the Notation of Venus Synodical Cycles in the Mexican Codices." Proceedings of the second SEAC Conference, Bochum, August 29th-31 $1^{\text {st }}$, 1994. Ed. 
W. Schlosser, Bochum: Astronomisches Institut der Ruhr Universität, (1996): 115-124.

"The Moon and the Genesis of the Mesoamerica 260-day Count." Astronomical Traditions in Past Cultures. Eds. V. Koleva and D. Kolev, Sofia: Institute of Astronomy, Bulgarian Academy of Sciences and National Astronomical Observatory Rozhen, (1996): 167-174.

"Los Nueve Señores de la Noche en función de Guardianes del Tiempo en los Códices Mesoamericanos." Estudios Latinoamericanos 18 (1998): 129-144.

"La "Piedra del Sol" y la lectura de los mistos cosmogónicos." Estudios Latinoamericanos 19 (1999): 87-144.

"El problema de la subdivisión interna del ciclo de 584 días en el Códice Dresde y la múltiple función de los números adicionales." Itinerarios 2 (1999): 132-177.

"The Sun Counts in the Dresden Codex. An interpretation of pages 24 and 4650." Actes de la Vème Conférence Annuelle de la SEAC. Eds. A. Lebeuf, and M. S. Ziółkowski, Warsaw and Gdańsk: Département d’Anthropologie Historique, Institut d'Archéologie de l'Université de Varsovie, Musée Maritime Central (1999): 285-296.

„Domesticating the Landscape - The Problem of the 17-degree Family Orientation in Mesoamerica“. Astronomy and Cultural Diversity. Eds. C. Esteban and J. A. Belmonte, San Cristobal de La Laguna, OACIMC (2000): 255-261.

"The Solar Year and the Dresden Codex." Latin American Indian Literatures Journal 17.2 (2001): 136-159.

"La tabla de eclipses del Códice de Dresde como tabla venusino-lunar." Etno y arqueoastronomía en las Américas. Eds. M. Boccas, J. Broda and G. Pereira, Memorias del Simposio ARQ- 13 del $51^{\circ}$ Congreso Internacional de Americanistas, Santiago de Chile (2004): 211-223.

"Domesticando el paisaje II: el horizonte como tabla del tonalpohualli." Reescritura e intertextualidad: literatura-cultura-historia. Ed. U. Aszyk, Varsovia: Instituto de Estudios Ibéricos e Iberoamericanos de la Universidad de Varsovia, Museo de Historia del Movimiento Campesino Polaco (2007): 331-347.

\section{Publications co-authored with Marek Siarkiewicz}

"Problemas de la correlación de calendarios cristiano y xihuitl (solar) de los pueblos del altiplano central en México.” Ethnologia Polona 8 (1982): 161-169.

"Algunos sistemas calendáricos de los pueblos del altiplano central de México y el problema de correlación con los calendarios cristianos." Revista Española de Antropología Americana 15 (1985): 121-129. 


\section{Archaeoastronomical works of Robert M. Sadowski}

Sadowski, R.M.

"The sky above the Incas: an abridged astronomical calendar for the 16th century". Time and Calendars in the Inca Empire. Eds. M.S. Ziolkowski and R.M. Sadowski, BAR International series, 479. Oxford: B.A.R., 1989: 75-106.

"A few remarks on the astronomy of R.T. Zuidema's quipu-calendar". Time and Calendars in the Inca Empire. Eds. M. S. Ziolkowski and R. M. Sadowski, BAR International Series, 479. Oxford: B.A.R. 1989: 209-213.

Ziolkowski, Mariusz S. and Robert M. Sadowski

"Los datos astronómicos en la crónica de Montesinos, informe preliminar, núm. 1." Estudios Latinoamericanos 5 (1979): 173-177.

“The Astronomical Data in Fernando Montesinos' Peruvian Chronicle: The Comets of Qhapaq Yupanki”. Archaeoastronomy, The Bulletin of The Center for Archaeoastronomy 3.2 (1980): 22-26.

"Los cometas de Qhapaq Yupanki: ¿Un aporte a la datación de la dinastía de los inkas?" Boletín de Lima 13 (1981): 19-24.

“Archeoastronomiczne badania Huaca Tres Palos (Perú).” Mieszkańcy Andów i ich środowisko, materiały z sesji naukowej. Kraków: Polskie Towarzystwo Studiów Latynoamerykańskich, 1981: 45-67.

"Los problemas de la reconstrucción de los calendarios prehispánicos andinos." Estudios Latinoamericanos 9 (1982-1984): 45-87.

Also published in

Katunob, Occasional publications in Mesoamerican Anthropology 28 (1984): 59-91.

"Informe acerca de las investigaciones arqueoastronómicas en el área central de

Ingapirca." Revista Española de Antropología Americana 14 (1984): 103-125.

"Informe de la segunda temporada de investigaciones arqueoastronómicas en Ingapirca, Ecuador.” Memorias del Primer Simposio Europeo sobre Antropología del Ecuador. Ed. S. E. Moreno Yañez, Quito: Instituto de Antropología Cultural, Universidad de Bonn and Ediciones Abya-Yala, 1985: 91-116.

"La función astronómica del centro ceremonial-administrativo inca en Ingapirca (Ecuador).” Colloquio Internazionale Archeologia e Astronomia, Venezia 3-6 Maggio 1989. Rivista di Archeologia, supplementi 9 (1991): 151-162.

La arqueoastronomía en la investigación de las culturas andinas. Quito: Banco Central del Ecuador and Instituto Otavaleño de Antropología, 1992.

Ziolkowski, Mariusz S. and Robert M. Sadowski, eds.

Time and Calendars in the Inca Empire. BAR International Series, 479. Oxford: B.A.R., 1989.

"The reconstruction of the metropolitan calendar of the Incas in the period 15001572 AD." Time and Calendars in the Inca Empire. Eds. M.S. Ziolkowski and R.M. Sadowski. BAR International series, 479. Oxford: B.A.R. 1989: 167-196. 
Tomicki, Ryszard and Robert M. Sadowski

"The night of Blas Botello: on a certain astrological prediction during the conquest of Mexico." Readings in Archaeoastronomy. Ed. S. Iwaniszewski, Warsaw: State Archaeological Museum and Department of Historical Anthropology, University of Warsaw, 1992: 84-86.

\section{Archaeoastronomical works of Arnold Lebeuf}

Les éclipses dans l'ancien Mexique, Cracovie: éditions de l'Université Jagiellone, 2003.

"Astronomía en Xochicalco". La Acrópolis de Xochicalco. Ed. J. Wimer, Cuernavaca: Instituto de Cultura de Morelos, 1995: 211-297.

"Une nouvelle aproche de la table des éclipses du Codex du Dresde." Actas del IV Congreso de la SEAC “Astronomía en la Cultura”. Eds. C. Jaschek and F. Atrio Barandela, Salamanca: Universidad de Salamanca, 1997: 173-184.

"Le Temple du Serpent a Plumes de Xochicalco et le problema des inscriptions de sa façade ouest." Ancient Times, Ancient Methods: Proceedings of the Third SEAC Conference. Ed. F. Stanescu. Sibiu: University of Sibiu “Lucian Blaga," 1999: 97-122.

"Une possibilité de datation absolute de la table d'éclipses du Codex de Dresde." Astronomy and Cultural Diversity. Eds. C. Esteban and J.A. Belmonte. San Cristobal de La Laguna: OACIMC, 2000: 225-231.

"Kalendarz dawnego Meksyku." Czas i kalendarz. Kraków: Papieska Akademia Teologiczna, 2000: 363-376.

"Dating the five Suns of Aztec Cosmology." Culture and Cosmos 8.1-2 (2005): 183-195.

"Le soleil nous porte ombrage." Lights and Shadows in Cultural Astronomy. Eds. M.P. Zedda and J.A. Belmonte. Isili: Associazione Archeofila Satda, 2007: 155-164.

"El Sol 4-Ollin de los Aztecas." Arqueologia 39 (2008): 108-141.

"4-Ollin, the Aztec Creation of a Fifth Sun." Image and Ritual in the Aztec World. Ed. Sylvie Peperstraete, BAR International Series 1896, Oxford: B.A.R., 2009: 70-99.

"A single mention of a fourth Cosmological System in Mesoamerica." Cosmology across Cultures. Eds. J. B. Rubiño-Martín, J. A. Belmonte, F. Prada, and A. Alberdi, Astronomical Society of the Pacific Conference Series, 409, San Francisco: Astronomical Society of the Pacific, 2009: 283-288.

"1-Tochtli, 2-Acatl, 1558/1559, 1610/1611. Reminiscencias de la Ceremonia del Fuego Nuevo." Estudios Latinoamericanos 30 (2010): 107-128.

“4-Ollin, aztecka kreacja Piątego Słońca.” Indigena. Przeszłość i Współczesność Tubylczych Kultur Amerykańskich 2 (2012): 8-46.

"A Possible native Site of Alignment in Baja California, Mexico." Anthropological Notebooks, 19 supplement (2013): 381-390.

"The cave of the astronomers at Xochicalco." Handbook of Archaeoastronomy and Ethnoastronomy. Ed. C.L.N. Ruggles, New York: Springer, 2014: 749-758. 
Ziolkowski, M. S. and A. Lebeuf

„Les Incas étaient-ils capables de prévoir les éclipses de lune?” Astronomie et Sciences Humaines 7 (1992): 23-41.

“Les Incas étaient-ils capables de prévoir les éclipses de lune?" Readings in Archaeoastronomy. Ed. S. Iwaniszewski, Warsaw: State Archaeological Museum and Department of Historical Anthropology, University of Warsaw, 1992: 71-83.

"Were the Incas able to predict lunar eclipses?" Archaeoastronomy in the 1990s. Ed. C.L.N. Ruggles, Loughborough: Group D. Publications, 1993: 298-308.

Lebeuf, A. and S. Iwaniszewski

"The New Fire Ceremony as an Harmonical Base to the Mesoamerican Calendrical System and Astronomy." Time and Astronomy at the Meeting of Two Worlds. Eds. S. Iwaniszewski, A. Lebeuf, A. Wierciński, and M. S. Ziółkowski, Studies and Materials 10, Warsaw: Center for Latin American Studies, University of Warsaw, 1994: 181-206.

Stanisław Iwaniszewski - Dr. habil., Professor-Researcher of Archaeology at the Escuela Nacional de Antropología e Historia - Instituto Nacional de Antropología e Historia, Mexico City, and the State Archaeological Museum in Warsaw. Former President of the European Society for Astronomy in Culture SEAC (1999-2005) and International Society for Archaeoastronomy and Astronomy in Culture (2007-2014), he teaches Archaeology of Identity, Landscape and Symbolic Archaeologies, and Archaeoastronomy. He has tutored 19 doctoral dissertations and authored over 150 academic papers, edited or coedited 9 books. In 2018, the European Society for Astronomy in Culture awarded him the Carlos Jaschek Medal for outstanding contributions in the fields of archaeoastronomy and cultural astronomy in 2018. His current research projects include The Lunar Theory of the Maya and Starry Skies - Animated Skies. 